\title{
KONSISTENSI REAKSI PASAR MODAL INDONESIA TERHADAP PENERBITAN INDEKS SRI-KEHATI
}

\author{
Lindananty $^{1^{*}}$, Mohammad Soedarman ${ }^{1}$ \\ ${ }^{1}$ STIE Malangkucecwara Malang \\ Jalan Terusan Candi Kalasan, Blimbing, Malang 65142, Indonesia \\ * Penulis Korespondensi; E-mail: lindana@stie-mce.ac.id
}

\begin{abstract}
Abstrak
Penelitian ini meneliti reaksi pasar modal Indonesia terhadap penerbitan Indeks SRI-KEHATI pada tahun 2009 sampai tahun 2013 (sembilan periode). Hasilnya menunjukkan bahwa tidak ada reaksi pasar modal Indonesia terhadap penerbitan Indeks SRI-KEHATI bila diukur dengan abnormal return, dan hasil ini konsisten selama sembilan periode. Akan tetapi, hasilnya berbeda bila diukur dengan trading volume activity, yaitu ada reaksi pasar pada periode 4, 6, dan 7, tetapi tidak ada reaksi pasar pada periode 1,2, 3, 5, 8, dan 9, berarti reaksi pasar tidak konsisten.
\end{abstract}

Kata kunci: Indeks SRI-KEHATI, reaksi pasar modal, abnormal return, trading volume activity

\begin{abstract}
The objective of this research was described Indonesian capital market reaction to the publication of the SRI-KEHATI Index during 2009 until 2013 (nine periods). The results showed that the Indonesian capital market did not react to the SRI-KEHATI Index while measured using abnormal return, and these results were consistent for nine periods. However, different result occurred when it measured by trading volume activity, there was a market reaction in period 4, 6, dan 7, but there was no market reaction in period 1, 2, 3, 5,8 , and 9, it meant that the market reaction didn't consistent.
\end{abstract}

Keywords: SRI-KEHATI index, stock market reaction, abnormal return, trading volume activity

\section{Pendahuluan}

Indeks SRI-KEHATI dibentuk oleh Bursa Efek Indonesia (BEI) dan Yayasan Keanekaragaman Hayati Indonesia (SRI-KEHATI) yang diterbitkan pada tanggal 8 Juni 2009. Hal tersebut merupakan jawaban terhadap tuntutan global berupa industri yang mengedepankan kepedulian pada lingkungan dan kemanusiaan, pelestarian dan pemanfaatan keanekaragaman hayati.

Indeks SRI-KEHATI telah diluncurkan selama empat tahun dan bagaimana reaksi pasar modal selama empat tahun ini? Penelitian tentang reaksi pasar modal Indonesia terhadap keberadaan Indeks SRIKEHATI telah diteliti oleh beberapa peneliti terdahulu yaitu Tangketasik (2010), Kusumawardani (2012), dan Renovan (2012) yang menemukan bahwa tidak ada perbedaan pada variabel abnormal return (AR) dan trading volume activity (TVA) sebelum dan sesudah penerbitan Indeks SRI-KEHATI pada tahun 2000 dan 2012.

Kesamaan hasil penelitian ketiga peneliti terdahulu menimbulkan pertanyaan apakah hal tersebut mencerminkan bahwa investor pasar modal Indonesia adalah investor yang tidak pro lingkungan dan kemanusiaan. Oleh karena itu, perlu dilakukan penelitian tentang reaksi pasar modal Indonesia pada terhadap penerbitan Indeks SRI-KEHATI selama periode 2009 -2013 agar dapat diketahui konsistensi reaksi pasar modal terhadap penerbitan Indeks SRI-KEHATI selama sembilan periode penerbitan indeks ini.

\section{Indeks Sri-Kehati}

Indeks SRI-KEHATI terdiri atas 25 saham yang dipilih melalui dua tahap seleksi yaitu seleksi awal untuk memilih saham yang berpotensi menjadi anggota indeks dan seleksi kedua dengan mempertimbangkan kinerja fundamental perusahaan. Seleksi awal untuk memilih saham yang berpotensi menjadi anggota indeks SRI-KEHATI, yaitu dengan mempertimbangkan kriteria-kriteria yakni: 1) Total Asset. Total asset mempresentasikan ukuran dari emiten SRI, yakni emiten-emiten yang memiliki total aset di atas Rp 1 triliun berdasarkan laporan keuangan auditan tahunan. 2) Price Earning Ratio (PER). PER 
emiten yang termasuk dalam kriteria ini adalah yang memiliki PER positif. 3) Free Float Ratio. Free float ratio atau kepemilikan saham publik harus lebih besar dari $10 \%$. Selanjutnya untuk memilih 25 saham yang terbaik, dilakukan pemeringkatan lebih lanjut berdasarkan aspek fundamental yaitu dengan mempertimbangkan enam faktor utama yakni (Bursa Efek Indonesia, 2010) lingkungan (environmental), pengembangan masyarakat (community), tata kelola perusahaan (corporate governance), hak asasi manusia (human rights), perilaku bisnis (business behaviour), dan praktek perburuhan dan praktik ketenagakerjaan (labour practices \& decent work).

\section{Abnormal Return Saham}

Reaksi pasar modal ditunjukkan dengan perubahan harga saham perusahaan yang diukur dengan abnormal return (AR). AR saham adalah hasil selisih antara return sesungguhnya yang terjadi dengan return ekspektasi (Jogiyanto, 2003, p. 416). Pengukuran AR dapat menggunakan beberapa metode, salah satunya adalah metode penyesuaian pasar (market adjusted model) yaitu model yang menganggap bahwa penduga terbaik untuk mengestimasi return suatu saham adalah return indeks pasar pada saat tersebut.

\section{Trading Volume Activity}

Trading volume activity (TVA) merupakan aktivitas perdagangan saham yang terjadi pada periode tertentu yang dihitung dengan membandingkan antara volume saham yang diperdagangkan dengan volume saham yang beredar. Konsep mengenai volume saham beranggapan bahwa kenaikan atau penurunan harga saham yang disertai TVA yang besar merupakan tanda kekuatan pasar, sedangkan pergerakan yang tidak disertai dengan TVA yang besar merupakan tanda pasar yang lemah.

\section{Penelitian Terdahulu}

Penelitian terkait dengan sosial dan lingkungan telah dilakukan oleh beberapa peneliti terdahulu pada pasar modal luar negeri yaitu penelitian di São Paulo Stock Exchange (Bovespa) oleh Nossa, Cezar, Silva Júnior, Baptista, and Nossa (2009). Penelitian tersebut meneliti hubungan antara abnormal return dan kinerja sosial dan lingkungan perusahaan pada 100 perusahaan yang di-ranking berdasarkan nilai pasar terbesar antara tahun 1999 dan tahun 2006. Hasil penelitian menunjukkan bahwa indikator tanggung jawab sosial eksternal, indikator tanggung jawab sosial internal dan indikator tanggung jawab lingkungan tidak mempunyai hubungan dengan abnormal return perusahaan

Penelitian di Amerika Serikat menunjukkan respon harga saham terhadap pengumuman indeks Toxic 100 perusahaan Amerika Serikat yang merupakan pencemar udara terbesar tahun 2006 dan tahun 2008. Hasilnya menunjukkan rata-rata abnormal return negatif signifikan dan terjadi penurunan ratarata nilai pasar selama masa dua hari pada tahun 2006 dan tahun 2008. Perusahaan yang masuk dalam daftar 10 teratas indeks Toxic ini mempunyai abnormal return negatif yang signifikan lebih besar dibandingkan 10 perusahaan terbawah. Penelitian ini menunjukkan bahwa investor di Amerika Serikat adalah investor yang peduli lingkungan (Bettenhausen, Byrd, \& Cooperman, 2010)

Hasil Bettenhausen et al. (2010) ini berbeda dengan hasil penelitian Anderson-Weir (2010). Anderson-Weir (2010) meneliti dampak pemberian Green Scores dan Green Rankings perusahaan oleh Newsweek terhadap abnormal return. Hasilnya menunjukkan bahwa tidak ada, atau sangat minimal, dampak dari Green Scores dan Green Rankings pada abnormal return. Penelitian ini juga menunjukkan bahwa Unexpected Green Rankings berdampak signifikan terhadap abnormal return, berarti bahwa pasar modal bereaksi pada komponen yang tidak diantisipasi Newsweek Ranking.

Studi ini juga menemukan bahwa perusahaan yang menduduki peringkat lebih buruk dari yang diharapkan oleh pasar mempunyai abnormal return positif. Selain itu hasil membuktikan bahwa secara keseluruhan studi Newsweek Green memiliki dampak negatif pada pendapatan saham untuk semua perusahaan yang diteliti.

Penelitian di pasar modal Indonesia terkait penerbitan Indeks SRI-KEHATI dilakukan oleh Tangketasik (2010), Renovan (2012), dan Kusumawardani (2012). Ketiga penelitian ini memperoleh hasil yang sama, bahwa AR dan TVA tidak signifikan berubah di sekitar tanggal peluncuran dan tanggal pengamatan. Hal ini berarti bahwa informasi peluncuran Indeks SRI-KEHATI tidak direaksi oleh pasar.

Berdasarkan hasil penelitian terdahulu maka dapat dirumuskan hipotesis penelitian yakni $H_{l a}$ : Ada reaksi pasar yang ditunjukkan dengan adanya AR yang signifikan di sekitar tanggal penerbitan Indeks SRI-KEHATI. Selain itu adanya hipotesis lain yakni $H_{l b}$ : Ada reaksi pasar yang ditunjukkan dengan adanya TVA yang signifikan di sekitar tanggal penerbitan Indeks SRI-KEHATI. Kedua, $H_{2 a}$ : Terjadi perbedaan abnormal return yang signifikan sebelum dan sesudah penerbitan Indeks SRI-KEHATI. Hipotesis lainnya adalah $H_{2 b}$ : Terjadi perbedaan trading 
volume activity yang signifikan sebelum sesudah penerbitan Indeks SRI-KEHATI.

\section{Metode Penelitian}

Jenis penelitian yang akan digunakan pada penelitian ini adalah studi peristiwa (event study). Studi reaksi pasar modal merupakan studi peristiwa yang digunakan untuk menguji kandungan informasi (information content) dari suatu peristiwa (Jogiyanto, 2003, p. 318).

Populasi penelitian ini adalah semua perusahaan yang masuk dalam Indeks SRI-KEHATI pada periode tahun 2009-2013. Metode pengumpulan data yang digunakan adalah metode dokumentasi untuk memperoleh data harga saham, volume perdagangan saham, dan IHSG. Data diperoleh melalui website www.yahoo.finance.com dan dari Indonesian Capital Market Directory (ICMD) tahun 2010-2013 dengan periode waktu disajikan pada Tabel 1. Event window penelitian ini disajikan pada Gambar 1.

\begin{tabular}{|c|c|}
\hline-6 & 0 \\
\hline
\end{tabular}

\section{Gambar 1. Event Window}

Event window digunakan selama enam hari dengan pertimbangan bahwa jangka waktu berlakunya Indeks SRI-KEHATI adalah enam bulan sehingga pasar tidak beraksi cepat setelah indeks diterbitkan, diperkirakan pasar akan bereaksi pada hari ketiga hingga hari keenam.

Adapun variabel penelitian yang digunakan untuk mengukur reaksi pasar modal adalah:

\section{Abnormal Return (AR)}

AR adalah selisih dari return yang sesungguhnya terjadi dengan return yang diharapkan investor. Pengukuran AR yang digunakan adalah metode penyesuaian pasar (market adjusted model) yaitu model yang menganggap bahwa penduga terbaik untuk mengestimasi return suatu saham adalah return indeks pasar pada saat tersebut (Jogiyanto, 2003, p. 416) Penggunaan model ini akan me- nyebabkan return saham yang diestimasikan adalah sama dengan return indeks pasar.

$$
A R_{i t}=R_{i t}-E\left(R m_{t}\right)
$$

Keterangan:

$A R_{i t}=$ Abnormal return saham $i$ pada periode $t$

$R_{i t} \quad=$ Return saham $i$ pada periode $t$

$E\left(R m_{t}\right)=$ Expected return indeks pasar saham pada periode $t$

Perhitungan return indeks pasar menggunakan rumus:

$$
E\left(R m_{t}\right)=\frac{I H S G_{t}-I H S G_{t-1}}{I H S G_{t}}
$$

Keterangan:

$$
\begin{aligned}
E\left(R m_{t}\right)= & \text { Expected return indeks pasar saham } \\
& \text { pada periode } t \\
I H S G_{t}= & \text { Indeks harga saham gabungan pada } \\
& \text { periode } t \\
I H S G_{t-1}= & \text { Indeks harga saham gabungan pada } \\
& \text { periode } t-1
\end{aligned}
$$

2. Trading Volume Activity (TVA)

TVA adalah aktivitas perdagangan saham yang terjadi pada periode tertentu yang dihitung dengan membandingkan antara volume saham (jumlah saham) yang diperdagangkan dengan volume saham yang beredar.

$$
T V A_{i t}=\frac{\sum \text { Saham i yang diperdagan gkan pada periode ke }-\mathrm{t}}{\sum \text { Saham i yang beredar pada periode } \mathrm{t}}
$$

Langkah langkah analisis data yaitu:

1. Melakukan uji normalitas data menggunakan uji Kolmogorov-Smirnov $(K-S)$

2. Melakukan pengujian hipotesis secara statistik a. Uji hipotesis la dan $1 \mathrm{~b}$ menggunakan uji $t$ untuk menguji reaksi pasar pada periode event window dengan hipotesis statistik sebagai berikut:

1) Hipotesis $1 \mathrm{a}$

$H_{0}: \mu=0$, tidak ada reaksi pasar yang ditunjukkan dengan tidak adanya AR yang signifikan di sekitar tanggal penerbitan Indeks SRI-KEHATI.

$H_{1}: \mu \neq 0$, ada reaksi pasar yang ditunjukkan dengan adanya AR yang signifikan di sekitar tanggal penerbitan Indeks SRI-KEHATI.

Tabel 1

Event Window

\begin{tabular}{clll}
\hline \multirow{2}{*}{ Periode Pengamatan } & \multicolumn{1}{c}{ Event Window } \\
\cline { 2 - 4 } 1 & \multicolumn{1}{c}{$-t$} & \multicolumn{1}{c}{$t$} & \multicolumn{1}{c}{$t+1$} \\
\hline 2 & 29 Mei-5 Juni 2009 & 8 Juni 2009 & 9 Juni-16 Juni 2009 \\
3 & 21-28 Oktober 2009 & 29 Oktober 2009 & 30 Oktober-6 November 2009 \\
4 & 22-29 April 2010 & 30 April 2010 & 3-10 Mei 2010 \\
5 & 21-28 Oktober 2010 & 29 Oktober 2010 & 1-8 November 2010 \\
6 & 18-28 April 2011 & 29 April 2011 & 2-9 Mei 2011 \\
7 & 20-27 Oktober 2011 & 28 Oktober 2011 & 31 Oktober-7 November 2011 \\
8 & 19-26 April 2012 & 27 April 2012 & 30 April-7 Mei 2012 \\
9 & 19-26 Oktober & 29 Oktober 2012 & 30 Oktober-6 November 2012 \\
\hline
\end{tabular}


2) Hipotesis $1 b$

$H_{0}: \mu=0$, tidak ada reaksi pasar yang ditunjukkan dengan tidak adanya TVA yang signifikan di sekitar tanggal penerbitan Indeks SRI-KEHATI.

$H_{1}: \mu \neq 0$, ada reaksi pasar yang ditunjukkan dengan adanya TVA yang signifikan di sekitar tanggal penerbitan Indeks SRI-KEHATI.

b. Uji hipotesis $2 \mathrm{a}$ dan $2 \mathrm{~b}$ menggunakan uji dua sampel berpasangan Sign Test untuk menguji ada tidaknya perbedaan AR dan TVA yang signifikan sebelum dan sesudah penerbitan Indeks SRI-KEHATI dengan hipotesis statistik sebagai berikut:

1) Hipotesis $2 a$ :

$H o: \mu_{1}=\mu_{2}$; tidak terjadi perbedaan abnormal return yang signifikan sebelum dan sesudah penerbitan Indeks SRI-KEHATI.

$H a: \mu_{1} \neq \mu_{2}$; terjadi perbedaan abnormal return yang signifikan sebelum dan sesudah penerbitan Indeks SRI-KEHATI.

2) Hipotesis $2 b$ :

$H_{0}: \mu_{1}=\mu_{2} ;$ tidak terjadi perbedaan trading volume activity yang signifikan sebelum dan sesudah penerbitan Indeks SRI-KEHATI.

Ha: $\mu_{1} \neq \mu_{2}$; terjadi perbedaan trading volume activity yang signifikan sebelum dan sesudah penerbitan Indeks SRI-KEHATI.

\section{Hasil Penelitian dan Pembahasan}

\section{Pengujian Reaksi Pasar Modal}

Hasil pengujian hipotesis 1 disajikan mulai Tabel 2 sampai dengan Tabel 10 dan pergerakan AR dan TVA disajikan mulai Gambar 3 sampai dengan Gambar 11. Hasil uji $t$ periode 1 disajikan pada Tabel 2. Pergerakan rata-rata AR dan rata-rata TVA dari 25 saham Indeks SRI-KEHATI pada periode 1, nampak pada Gambar 2.

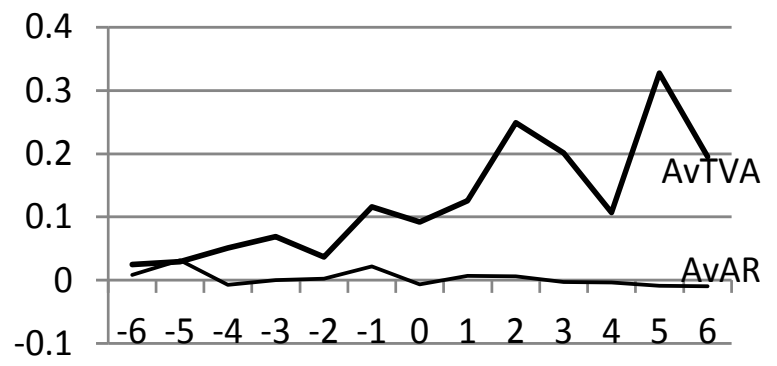

Gambar 2. Pergerakan Rata-Rata AR dan Rata-Rata TVA Periode 1

Hasil uji $t$ periode 1 pada Tabel 2 menunjukkan nilai rata-rata AR dan TVA di hari ke-6 s/d +6 secara statisitik tidak ada yang signifikan. Gambar 2 menunjukkan rata-rata $A R$ meningkat pada hari ke +1 setelah penerbitan Indeks SRI-KEHATI, namun menurun dimulai pada hari ke +3 . Akan tetapi, penurunan rata-rata AR tidak diikuti rata-rata TVA, terjadi peningkatan rata-rata TVA hingga hari ke +2 , kemudian berfluktuasi cukup tinggi pada hari +5 dan +6. Kondisi ini menunjukkan bahwa rata-rata AR

Tabel 2

Hasil Uji t Periode 1

\begin{tabular}{ccccc}
\hline \multirow{2}{*}{ Hari ke } & \multicolumn{2}{c}{ Variabel AR } & \multicolumn{2}{c}{ Variabel TVA } \\
\cline { 2 - 4 } & Rata-Rata AR & $t$ hitung & 0,0250 & $t, 295$ \\
-6 & 0,0083 & 0,270 & 0,0298 & 1,359 \\
-5 & 0,0315 & 0,940 & 0,0512 & 1,179 \\
-4 & $-0,0068$ & $-0,401$ & 0,0692 & 1,433 \\
-3 & 0,0002 & 0,007 & 0,0371 & 1,390 \\
-2 & 0,0026 & 0,135 & 0,1160 & 1,302 \\
-1 & 0,0217 & 0,773 & 0,0924 & 1,141 \\
0 & $-0,0064$ & $-0,271$ & 0,1254 & 1,222 \\
1 & 0,0068 & 0,553 & 0,2487 & 1,124 \\
2 & 0,0067 & 0,154 & 0,2010 & 1,201 \\
3 & $-0,0030$ & $-0,280$ & 0,1069 & 1,206 \\
4 & $-0,0033$ & $-0,262$ & 0,3272 & 1,146 \\
5 & $-0,0087$ & $-0,435$ & 0,1950 & 1,098 \\
6
\end{tabular}

Keterangan:

*signifikan pada tingkat $10 \%(t>1,711$ untuk pengujian dua sisi dengan $k=25)$

**signifikan pada tingkat 5\% ( $t>2,064$ untuk pengujian dua sisi dengan $k=25)$

***signifikan pada tingkat $1 \%(t>2,797$ untuk pengujian dua sisi dengan $k=25)$ 
Indeks SRI-KEHATI cenderung menurun setelah hari ke 0 dan disertai rata-rata TVA yang meningkat, namun perubahan ini tidak signifikan yang berarti perubahan rata-rata AR bukan disebabkan karena penerbitan Indeks SRI-KEHATI tetapi karena faktor lain.

Berdasarkan hasil signifikansi rata-rata AR dan rata-rata TVA periode 1 untuk masing-masing hari event window, menandakan penerbitan Indeks SRIKEHATI tidak mengandung informasi sehingga pasar tidak bereaksi pada periode awal penerbitan indeks ini. Hasil uji $t$ periode 2 disajikan pada Tabel 3.

Pergerakan rata-rata AR dan rata-rata TVA dari 25 saham Indeks SRI-KEHATI pada periode 2, nampak pada Gambar 3 .

Hasil uji $t$ periode 2 pada Tabel 3 menunjukkan nilai rata-rata AR dan rata-rata TVA di hari ke -6 s/d +6 secara statisitik tidak ada yang signifikan. Gambar 3 menunjukkan rata-rata $\mathrm{AR}$ tidak mengalami perubahan yang berarti mulai hari ke -6 hingga hari ke +6 . Berbeda dengan pergerakan rata-rata TVA yang sangat fluktuatif, dan terjadi peningkatan sejak hari ke +1 hingga hari ke +6 . Kondisi ini menunjukkan bahwa pergerakan rata-rata AR Indeks SRI-KEHATI cenderung tidak berubah setelah hari ke 0 dan disertai rata-rata TVA yang meningkat, namun perubahan ini tidak signifikan.

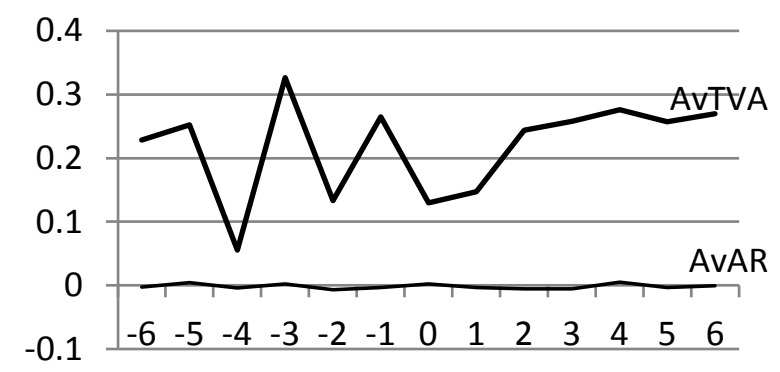

Gambar 3. Pergerakan Rata-Rata AR dan Rata-Rata TVA Periode 2

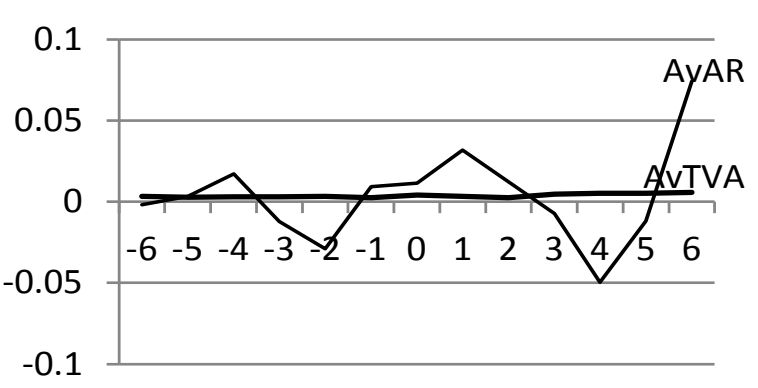

Gambar 4. Pergerakan Rata-Rata AR dan Rata-Rata TVA Periode 3.

Berdasarkan hasil signifikansi rata-rata AR dan rata-rata TVA periode 2 untuk masing-masing hari event window. Berarti penerbitan Indeks SRI-KEHATI tidak mengandung informasi sehingga pasar tidak bereaksi pada periode 2 penerbitan indeks ini. Hasil uji $t$ periode 3 disajikan pada Tabel 4.

Pergerakan rata-rata AR dan rata-rata TVA dari 25 saham Indeks SRI-KEHATI pada periode 3, nampak pada Gambar 4.

Hasil uji $t$ periode 3 pada Tabel 4 menunjukkan nilai rata-rata $\mathrm{AR}$ signifikan pada hari ke $0,+1,+2$, $+4,+5$ dan +6 . Hal ini menunjukkan bahwa pasar bereaksi terhadap penerbitan indeks ini pada hari-hari tersebut, tetapi tidak signifikan pada hari $\mathrm{ke}+3$. Ratarata TVA tidak ada yang signifikan pada hari event window.

Gambar 4 menunjukkan pergerakan rata-rata AR dan rata-rata TVA pada periode 3 sangat berbeda dengan periode 1 dan 2 . Periode 3 rata-rata AR mengalami fluktuasi yang sangat tinggi, meningkat pada hari ke +1 , menurun pada hari ke +2 hingga +4 , namun meningkat pada hari ke +5 dan meningkat tajam pada hingga hari ke +6 . Berbeda dengan pergerakan rata-rata TVA yang tidak mengalami perubahan berarti. Kondisi ini menunjukkan bahwa perubahan rata-rata AR yang signifikan dimulai lima

Tabel 3

Hasil Uji t Periode 2

\begin{tabular}{|c|c|c|c|c|}
\hline \multirow{2}{*}{ Hari ke } & \multicolumn{2}{|c|}{ Variabel AR } & \multicolumn{2}{|c|}{ Variabel AR } \\
\hline & Rata-Rata AR & $t$ hitung & Rata-Rata TVA & $t$ hitung \\
\hline-6 & $-0,0021$ & $-0,897$ & 0,2286 & 1,045 \\
\hline-5 & 0,0042 & 1,282 & 0,2519 & 1,026 \\
\hline-4 & $-0,0035$ & $-1,043$ & 0,0557 & 1,088 \\
\hline-3 & 0,0025 & 0,537 & 0,3265 & 1,047 \\
\hline-2 & $-0,0067$ & $-1,660$ & 0,1329 & 1,065 \\
\hline-1 & $-0,0033$ & $-0,577$ & 0,2646 & 1,094 \\
\hline 0 & 0,0023 & 0,536 & 0,1294 & 1,094 \\
\hline 1 & $-0,0028$ & $-0,609$ & 0,1473 & 1,087 \\
\hline 2 & $-0,0053$ & $-1,441$ & 0,2437 & 1,033 \\
\hline 3 & $-0,0052$ & $-1,456$ & 0,2577 & 1,025 \\
\hline 4 & 0,0053 & 1,003 & 0,2762 & 1,030 \\
\hline 5 & $-0,0029$ & $-0,707$ & 0,2567 & 1,025 \\
\hline 6 & $-0,0002$ & $-0,069$ & 0,2695 & 1,112 \\
\hline
\end{tabular}

Keterangan:

*signifikan pada tingkat $10 \%(t>1,711$ untuk pengujian dua sisi dengan $k=25)$

**signifikan pada tingkat 5\% ( $t>2,064$ untuk pengujian dua sisi dengan $k=25)$

$* * *$ signifikan pada tingkat $1 \%(t>2,797$ untuk pengujian dua sisi dengan $k=25)$ 
Tabel 4

Hasil Uji t Periode 3

\begin{tabular}{|c|c|c|c|c|}
\hline \multirow{2}{*}{ Hari ke } & \multicolumn{2}{|c|}{ Variabel AR } & \multicolumn{2}{|c|}{ Variabel TVA } \\
\hline & Rata-Rata AR & $t$ hitung & Rata-Rata TVA & $t$ hitung \\
\hline-6 & $-0,0018$ & $-0,626$ & 0,2286 & 0,094 \\
\hline-5 & 0,0033 & 0,773 & 0,2519 & 0,093 \\
\hline-4 & $0,0172 * * *$ & 4,815 & 0,0557 & 0,091 \\
\hline-3 & $-0,0121 * * *$ & $-3,428$ & 0,3265 & 0,091 \\
\hline-2 & $-0,0291 * * *$ & $-11,027$ & 0,1329 & 0,112 \\
\hline-1 & $0,0093 * * *$ & 3,563 & 0,2646 & 0,096 \\
\hline 0 & $0,0113 * * *$ & 3,555 & 0,1294 & 0,117 \\
\hline 1 & $0,0318 * * *$ & 7,772 & 0,1473 & 0,086 \\
\hline 2 & $0,0122 * *$ & 2,361 & 0,2437 & 0,105 \\
\hline 3 & $-0,0073$ & $-1,535$ & 0,2577 & 0,141 \\
\hline 4 & $-0,0496 * * *$ & $-11,405$ & 0,2762 & 0,130 \\
\hline 5 & $-0,0119 * * *$ & $-2,898$ & 0,2567 & 0,128 \\
\hline 6 & $0,0740 * * *$ & 2,362 & 0,2695 & 0,119 \\
\hline
\end{tabular}

Keterangan:

*signifikan pada tingkat $10 \%(t>1,711$ untuk pengujian dua sisi dengan $k=25)$

**signifikan pada tingkat 5\% ( $t>2,064$ untuk pengujian dua sisi dengan $k=25)$

***signifikan pada tingkat $1 \%(t>2,797$ untuk pengujian dua sisi dengan $k=25)$

Tabel 5

Hasil Uji t Periode 4

\begin{tabular}{ccccc}
\hline \multirow{2}{*}{ Hari ke } & \multicolumn{2}{c}{ Variabel AR } & \multicolumn{2}{c}{ Variabel TVA } \\
\cline { 2 - 5 } & Rata-Rata AR & $t$ hitung & $0,0022^{* * *}$ & $t$ hitung \\
\hline-6 & 0,0051 & 1,094 & $0,0022^{* * *}$ & 3,052 \\
-5 & $-0,0014$ & $-0,396$ & $0,0024 * * *$ & 2,876 \\
-4 & 0,0052 & 1,039 & $0,0022^{* * *}$ & 3,163 \\
-3 & $-0,0021$ & $-0,636$ & $0,0027 * * *$ & 2,809 \\
-2 & 0,0033 & 0,853 & $0,0023 * * *$ & 3,066 \\
-1 & 0,0006 & 0,185 & $0,0018 * * *$ & 3,606 \\
0 & $-0,0008$ & $-0,294$ & $0,0019 * * *$ & 3,603 \\
1 & $-0,0059$ & $-1,389$ & $0,0022^{* * *}$ & 4,033 \\
2 & 0,0023 & 0,661 & $0,0024 * * *$ & 3,484 \\
3 & $-0,0057$ & $-1,584$ & $0,0024 * * *$ & 3,675 \\
4 & 0,0064 & 1,502 & $0,0032 * * *$ & 2,945 \\
5 & $-0,0019$ & $-0,495$ & $0,0032 * * *$ & 3,524 \\
6 & $-0,0001$ & $-0,026$ & & \\
\hline
\end{tabular}

Keterangan:

*signifikan pada tingkat $10 \%(t>1,711$ untuk pengujian dua sisi dengan $k=25)$

**signifikan pada tingkat 5\% ( $t>2,064$ untuk pengujian dua sisi dengan $k=25)$

***signifikan pada tingkat $1 \%(t>2,797$ untuk pengujian dua sisi dengan $k=25)$

hari sebelum, pada hari ke 0 , dan 6 hari setelah penerbitan indeks kecuali hari ke +3 . Akan tetapi, perubahan rata-rata AR yang signifikan ini tidak diikuti dengan perubahan TVA yang signifikan.

Hasil signifikansi rata-rata AR dan rata-rata TVA periode 3 untuk masing-masing hari event window berarti penerbitan Indeks SRI-KEHATI mengandung informasi. Selain itu, pasar bereaksi lambat dan tidak berkepanjangan karena pada hari ke +3 pasar tidak beraksi, kemudian pada hari ke +4 hingga hari ke +6 pasar bereaksi kembali. Hasil uji $t$ periode 4 disajikan pada Tabel 5. Pergerakan rata-rata AR dan rata-rata TVA dari 25 saham Indeks SRI-KEHATI pada periode 4 nampak pada Gambar 5.

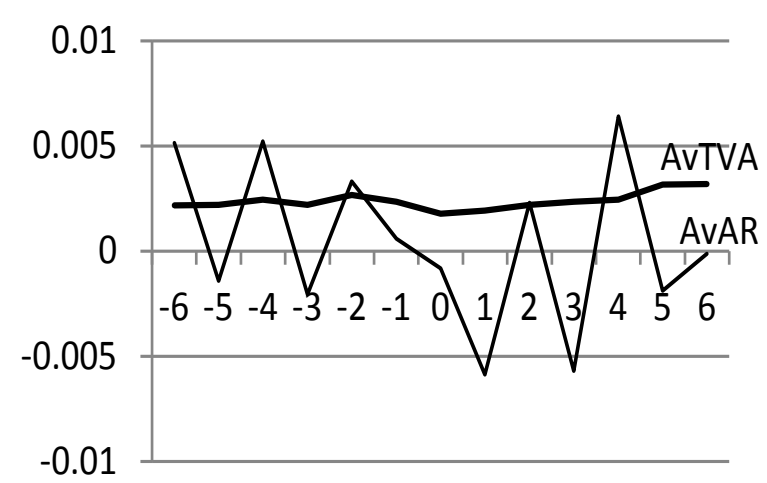

Gambar 5. Pergerakan Rata-Rata AR dan Rata-Rata TVA Periode 4 


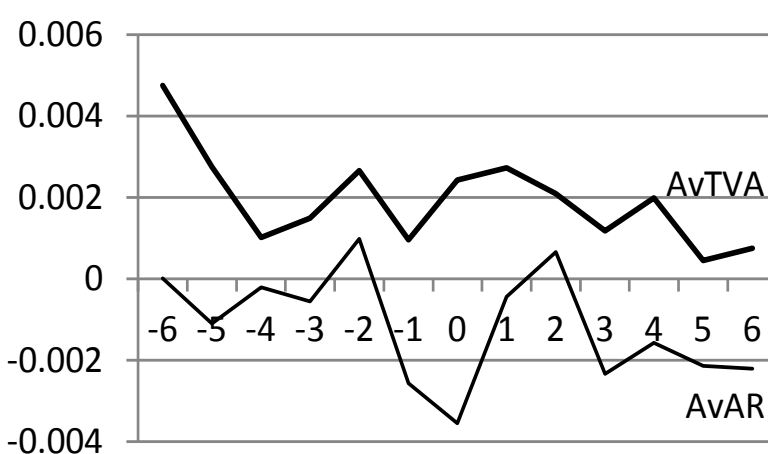

Gambar 6. Pergerakan Rata-Rata AR dan Rata-Rata TVA Periode 5

Hasil uji $t$ periode 4 pada Tabel 5 menunjukkan nilai rata-rata AR di hari $-6 \mathrm{~s} / \mathrm{d}+6$ secara statisitik tidak ada yang signifikan, namun pada rata-rata TVA di hari $-6 \mathrm{~s} / \mathrm{d}+6$ secara statistik signifikan pada level $\alpha$ $=1 \%$. Gambar 5 menunjukkan pergerakan rata-rata AR pada hari ke +1 hingga +6 sangat berfluktuasi. Pergerakan rata-rata TVA tidak mengalami perubahan berarti namun signifikan.

Berdasarkan hasil signifikansi rata-rata TVA periode 4 untuk masing-masing hari event window berarti penerbitan Indeks SRI-KEHATI mengandung informasi dan pasar bereaksi cepat dan berkepanjangan. Hasil ini menunjukkan bahwa pada periode 4 penerbitan Indeks SRI-KEHATI mengandung informasi sehingga pasar bereaksi walaupun tidak diikuti dengan signifikan pada rata-rata AR. Hasil uji $t$ periode 5 disajikan pada Tabel 6. Pergerakan rata-rata AR dan rata-rata TVA dari 25 saham Indeks SRI-KEHATI pada periode 5, nampak pada Gambar 6.
Hasil uji $t$ periode 5 pada Tabel 6 menunjukkan nilai rata-rata AR di hari $-6 \mathrm{~s} / \mathrm{d}+6$ secara statisitik tidak ada yang signifikan, kecuali pada hari ke-1 sebelum penerbitan indeks. Rata-rata TVA di hari $-6 \mathrm{~s} / \mathrm{d}$ +6 secara statistik ada yang signifikan dan tidak signifikan. Gambar 6 menunjukkan pergerakan rata-rata AR dan rata-rata TVA pada hari ke- 6 hingga +6 berfluktuasi sangat tinggi. Terjadi peningkatan pergerakan rata-rata AR pada hari ke +1 dan +2 setelah penerbitan Indeks SRI-KEHATI, namun menurun setelah hari ke +2 .

Berdasarkan hasil signifikansi rata-rata TVA periode 5 untuk hari event window $-6,-5,-3,-2,0,+1$, $+2,+4$ berarti penerbitan Indeks SRI-KEHATI mengandung informasi dan pasar bereaksi lambat dan tidak berkepanjangan. Hasil ini menunjukkan bahwa pada periode 5 penerbitan Indeks SRI-KEHATI mengandung informasi tetapi tidak sepanjang event window. Dapat disimpulkan ada reaksi pasar walaupun tidak panjang. Hasil uji $t$ periode 6 disajikan pada Tabel 7.

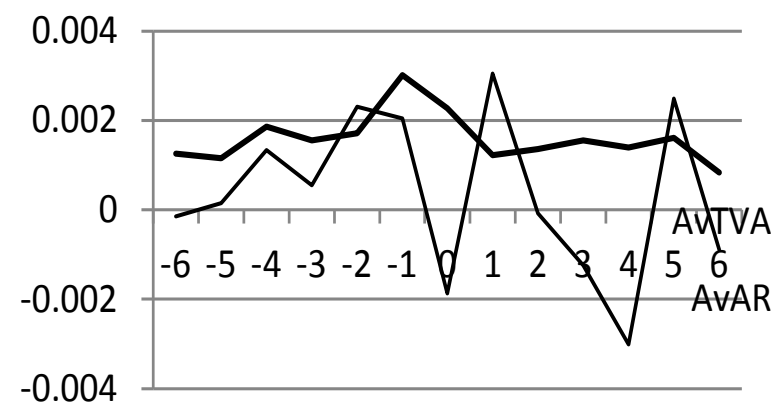

Gambar 7. Pergerakan Rata-Rata AR dan Rata-Rata TVA Periode 6

Tabel 6

Hasil Uji t Periode 5

\begin{tabular}{ccrcc}
\hline \multirow{2}{*}{ Hari ke } & \multicolumn{2}{c}{ Variabel AR } & \multicolumn{2}{c}{ Variabel TVA } \\
\cline { 2 - 5 } & Rata-Rata AR & $t$ hitung & Rata-Rata TVA & $t$ hitung \\
\hline-6 & 0,0001 & 0,040 & $0,0047^{*}$ & $0,0027^{* * *}$ \\
-5 & $-0,0008$ & $-0,318$ & 0,0010 & 2,908 \\
-4 & $-0,0003$ & $-0,124$ & $0,0015^{*}$ & 1,635 \\
-3 & $-0,0010$ & $-0,403$ & $0,0027^{* * *}$ & 2,907 \\
-2 & 0,0016 & 0,498 & 0,0010 & 1,261 \\
-1 & $-0,0031^{*}$ & $-1,803$ & $0,0024^{* * *}$ & 3,144 \\
0 & $-0,0024$ & $-0,831$ & $0,0027^{* *}$ & 2,399 \\
1 & $-0,0007$ & $-0,265$ & $0,0021^{* *}$ & 2,451 \\
2 & 0,0016 & 0,714 & 0,0012 & 1,687 \\
3 & $-0,0029$ & $-1,010$ & $0,0020^{* * *}$ & 4,176 \\
4 & $-0,0005$ & $-0,181$ & 0,0005 & 0,376 \\
5 & $-0,0032$ & $-1,220$ & 0,0007 & 1,061 \\
6
\end{tabular}

Keterangan:

*signifikan pada tingkat $10 \%(t>1,711$ untuk pengujian dua sisi dengan $k=25)$

**signifikan pada tingkat 5\% ( $t>2,064$ untuk pengujian dua sisi dengan $k=25)$

$* * *$ signifikan pada tingkat $1 \%(t>2,797$ untuk pengujian dua sisi dengan $k=25)$ 
Tabel 7

Hasil Uji t Periode 6

\begin{tabular}{cccc}
\hline \multirow{2}{*}{ Hari ke } & \multicolumn{2}{c}{ Variabel AR } & Variabel TVA \\
\cline { 2 - 4 } & Rata-Rata AR & $t$ hitung & Rata-Rata TVA \\
\hline-6 & $-0,0001$ & $-0,033$ & $0,0013 * * *$ \\
-5 & 0,0002 & 0,062 & $0,0011^{* * *}$ \\
-4 & 0,0013 & 0,278 & $0,0019 * * *$ \\
-3 & 0,0005 & 0,204 & $0,0015 * * *$ \\
-2 & 0,0023 & 0.763 & $0,0017 * * *$ \\
-1 & 0,0020 & 0,509 & $0,0030 * * *$ \\
0 & $-0,0019$ & $-0,390$ & $0,0023 * * *$ \\
1 & 0,0031 & 0,944 & $0,0012 * * *$ \\
2 & $-0,0001$ & $-0,019$ & $0,0014 * * *$ \\
3 & $-0,0012$ & $-0,349$ & $0,0016^{* * *}$ \\
4 & $-0,0030$ & $-1,045$ & $0,0014 * * *$ \\
5 & 0,0025 & 0,823 & $0,0016^{* * *}$ \\
6 & $-0,0009$ & $-0,335$ & $0,0008^{* * *}$ \\
\hline
\end{tabular}

Keterangan:

*signifikan pada tingkat $10 \%(t>1,711$ untuk pengujian dua sisi dengan $k=25)$

**signifikan pada tingkat 5\% $(t>2,064$ untuk pengujian dua sisi dengan $k=25)$

$* * *$ signifikan pada tingkat $1 \%(t>2,797$ untuk pengujian dua sisi dengan $k=25)$

Tabel 8

Hasil Uji t Periode 7

\begin{tabular}{|c|c|c|c|c|}
\hline \multirow{2}{*}{ Hari ke } & \multicolumn{2}{|c|}{ Variabel AR } & \multicolumn{2}{|c|}{ Variabel TVA } \\
\hline & Rata-Rata AR & $t$ hitung & Rata-Rata TVA & $t$ hitung \\
\hline-6 & $-0,0034$ & $-0,832$ & $0,0020 * * *$ & 3,993 \\
\hline-5 & $-0,0026$ & $-1,029$ & $0,0020 * * *$ & 3,740 \\
\hline-4 & 0,0043 & 1,283 & $0,0018 * * *$ & 4,238 \\
\hline-3 & 0,0026 & 0,777 & $0,0020 * * *$ & 3,325 \\
\hline-2 & $-0,0008$ & $-0,220$ & $0,0034 * *$ & 2,156 \\
\hline-1 & $-0,0018$ & $-0,494$ & $0,0031 * *$ & 2,548 \\
\hline 0 & 0,0019 & 0,443 & $0,0027 * * *$ & 3,194 \\
\hline 1 & 0,0030 & 0,832 & $0,0027 * * *$ & 3,336 \\
\hline 2 & 0,0022 & 0,431 & $0,0015 * * *$ & 3,763 \\
\hline 3 & $-0,0022$ & $-0,617$ & $0,0030 * * *$ & 3,821 \\
\hline 4 & $-0,0005$ & $-0,202$ & $0,0032 * *$ & 2,550 \\
\hline 5 & $-0,0027$ & $-0,880$ & $0,0022 * * *$ & 3,197 \\
\hline 6 & 0,0023 & 0,738 & $0,0022 * * *$ & 3,789 \\
\hline
\end{tabular}

Keterangan:

*signifikan pada tingkat 10\% ( $t>1,711$ untuk pengujian dua sisi dengan $k=25)$

$* *$ signifikan pada tingkat 5\% ( $t>2,064$ untuk pengujian dua sisi dengan $k=25)$

$* * *$ signifikan pada tingkat $1 \%(t>2,797$ untuk pengujian dua sisi dengan $k=25)$

Pergerakan rata-rata AR dan rata-rata TVA dari 25 saham Indeks SRI-KEHATI pada periode 6, nampak pada Gambar 7.

Hasil uji $t$ periode 6 pada Tabel 7 menunjukkan nilai rata-rata $A R$ di hari $-6 \mathrm{~s} / \mathrm{d}+6$ secara statisitik tidak ada yang signifikan, namun pada rata-rata TVA di hari -6 s/d +6 secara statistik signifikan pada level $\alpha$ $=1 \%$. Gambar 7 menunjukkan pergerakan rata-rata AR yang sangat berfluktuasi tetapi tidak signifikan, sedangkan pergerakan rata-rata TVA yang berfluktuasi rendah namun signifikan.

Berdasarkan hasil signifikansi rata-rata TVA periode 6 untuk masing-masing hari event window berarti penerbitan Indeks SRI-KEHATI mengandung informasi dan pasar bereaksi cepat dan berkepanjangan. Hasil ini menunjukkan bahwa pada periode 6 penerbitan Indeks SRI-KEHATI mengandung infor- masi sehingga pasar bereaksi walaupun tidak diikuti dengan signifikan pada rata-rata AR. Hasil uji $t$ periode 7 disajikan pada Tabel 8. Pergerakan rata-rata AR dan rata-rata TVA dari 25 saham Indeks SRIKEHATI pada periode 7, nampak pada Gambar 8.

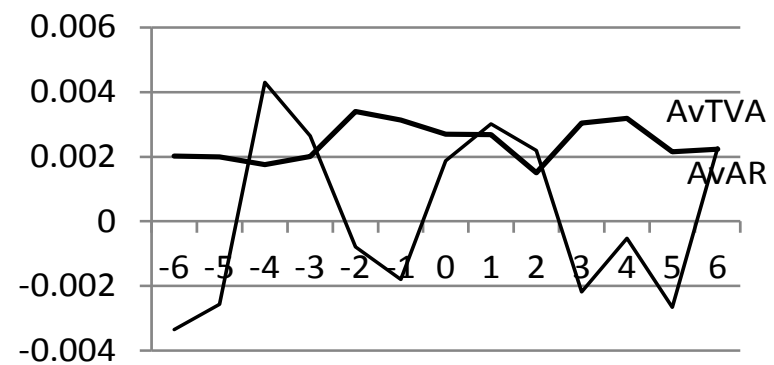

Gambar 8. Pergerakan Rata-Rata AR dan Rata-Rata TVA Periode 7 


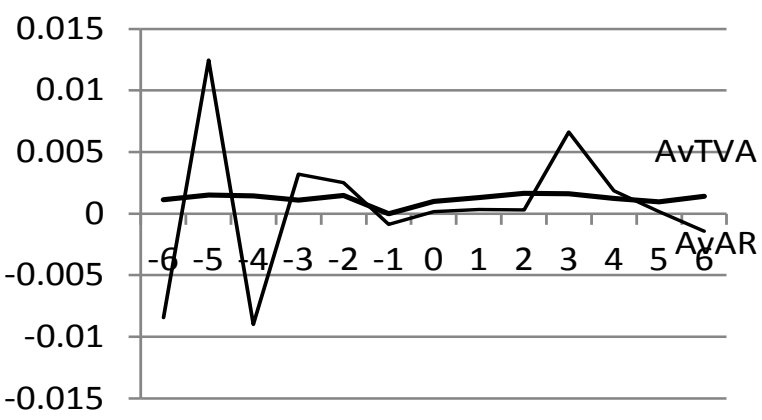

Gambar 9. Pergerakan Rata-Rata AR dan Rata-Rata TVA Periode 8

Hasil uji $t$ periode 7 pada Tabel 8 menunjukkan nilai rata-rata AR di hari $-6 \mathrm{~s} / \mathrm{d}+6$ secara statisitik tidak ada yang signifikan, namun pada rata-rata TVA di hari $-6 \mathrm{~s} / \mathrm{d}+6$ secara statistik signifikan pada level $\alpha$ $=1 \%$ dan $\alpha=5 \%$. Gambar 8 menunjukkan pergerakan rata-rata AR dan rata-rata TVA pada hari ke +1 hingga +6 sama-sama berfluktuasi seperti pada periode 6. Namun, tingkat fluktuasi rata-rata AR lebih tinggi dibandingkan rata-rata AR pada periode 6 . Tingkat fluktuasi rata-rata TVA tidak tinggi, sama seperti pada periode 6 .

Berdasarkan hasil signifikansi rata-rata TVA periode 7 pada setiap hari event window menunjukkan bahwa penerbitan Indeks SRI-KEHATI pada periode 7 mengandung informasi, sehingga pasar bereaksi. Hasil uji $t$ periode 8 disajikan pada Tabel 9. Pergerakan rata-rata $\mathrm{AR}$ dan rata-rata TVA dari 25 saham Indeks SRI-KEHATI pada periode 8, nampak pada Gambar 9.

Hasil uji periode 8 pada Tabel 9 menunjukkan nilai rata-rata $A R$ di hari $-3 \mathrm{~s} / \mathrm{d}+6$ secara statisitik tidak signifikan, kecuali pada hari ke $-4,-5$, dan -6 signifikan. Rata-rata TVA di hari -6 s/d +6 secara statistik signifikan kecuali hari ke 0, -1 dan -6 tidak signifikan. Gambar 9 menunjukkan pergerakan rata-rata AR pada hari ke +1 hingga +6 berfluktuasi namun tidak setinggi pada periode 7 . Pergerakan rata-rata TVA tidak terjadi perubahan yang berarti.

Berdasarkan hasil signifikansi rata-rata TVA periode 8 pada setiap hari event window menunjukkan bahwa penerbitan Indeks SRI-KEHATI pada periode 8 mengandung informasi sehingga pasar bereaksi. Hasil uji $t$ periode 9 disajikan pada Tabel 10.

Pergerakan rata-rata AR dan rata-rata TVA dari 25 saham Indeks SRI-KEHATI pada periode 9, nampak pada Gambar 10.

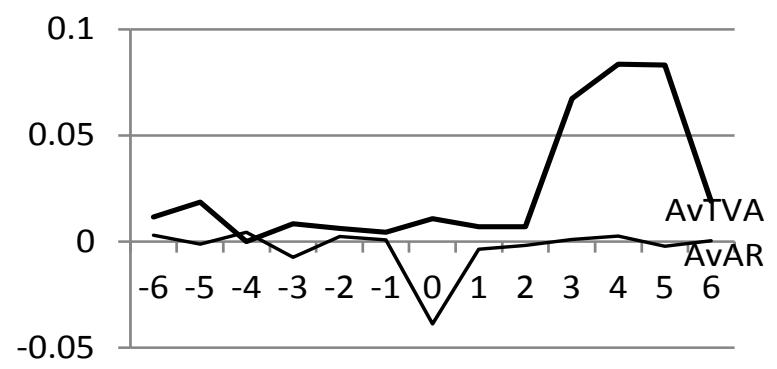

Gambar 10. Pergerakan Rata-Rata AR dan Rata-Rata TVA Periode 9

Hasil uji $t$ periode 9 pada Tabel 10 menunjukkan nilai rata-rata AR dan rata-rata TVA di hari ke $-6 \mathrm{~s} / \mathrm{d}$ +6 secara statisitik tidak ada yang signifikan. Gambar 10 pergerakan rata-rata AR pada hari ke +1 hingga +6 meningkat. Pergerakan rata-rata TVA meningkat hingga hari ke +4 lalu menurun tajam pada hari ke +6 .

Tabel 9

Hasil Uji t Periode 8

\begin{tabular}{|c|c|c|c|c|}
\hline \multirow{2}{*}{ Hari ke } & \multicolumn{2}{|c|}{ Variabel AR } & \multicolumn{2}{|c|}{ Variabel TVA } \\
\hline & Rata-Rata AR & $t$ hitung & Rata-Rata TVA & $t$ hitung \\
\hline-6 & $-0,0084 * * *$ & $-3,014$ & $0,0011 * * *$ & 2,94 \\
\hline-5 & $0,0125 * * *$ & 3,589 & $0,0015^{* *}$ & 2,26 \\
\hline-4 & $-0,0090 * * *$ & $-3,553$ & $0,0014 * *$ & 2,35 \\
\hline-3 & 0,0032 & 1,602 & $0,0011 * * *$ & 4,84 \\
\hline-2 & 0,0025 & 0,892 & $0,0015^{* *}$ & 2,55 \\
\hline-1 & $-0,0009$ & 0,000 & 0,0000 & - \\
\hline 0 & 0,0002 & 0,048 & $0,0010 * * *$ & 4,90 \\
\hline 1 & 0,0003 & 0,093 & $0,0013 * * *$ & 3,43 \\
\hline 2 & 0,0003 & 0,114 & $0,0016^{* * *}$ & 3,13 \\
\hline 3 & 0,0066 & 1,536 & $0,0016^{* * *}$ & 3,97 \\
\hline 4 & 0,0018 & 0,686 & $0,0012 * * *$ & 3,76 \\
\hline 5 & 0,0002 & 0,069 & $0,0010 * * *$ & 5,30 \\
\hline 6 & $-0,0014$ & $-0,594$ & $0,0014 * * *$ & 3,93 \\
\hline
\end{tabular}

Keterangan:

*signifikan pada tingkat $10 \%(t>1,711$ untuk pengujian dua sisi dengan $k=25)$

**signifikan pada tingkat 5\% ( $t>2,064$ untuk pengujian dua sisi dengan $k=25)$

$* * *$ signifikan pada tingkat $1 \%(t>2,797$ untuk pengujian dua sisi dengan $k=25)$ 
Tabel 10

Hasil Uji t Periode 9

\begin{tabular}{|c|c|c|c|c|}
\hline \multirow{2}{*}{ Hari ke } & \multicolumn{2}{|c|}{ Variabel AR } & \multicolumn{2}{|c|}{ Variabel TVA } \\
\hline & Rata-Rata AR & $t$ hitung & Rata-Rata TVA & $t$ hitung \\
\hline-6 & 0,0030 & 0,812 & 0,011 & 1,148 \\
\hline-5 & $-0,0013$ & $-0,504$ & 0,018 & 1,046 \\
\hline-4 & 0,0043 & 0,000 & 0,000 & 0,00 \\
\hline-3 & $-0,0074$ & $-1,414$ & 0,011 & 1,156 \\
\hline-2 & 0,0023 & 0,502 & 0,006 & 1,359 \\
\hline-1 & 0,0007 & 0,178 & 0,005 & 1,421 \\
\hline 0 & $-0,0389$ & $-0,963$ & 0,011 & 1,088 \\
\hline 1 & $-0,0036$ & $-0,468$ & 0,006 & 1,482 \\
\hline 2 & $-0,0019$ & $-0,470$ & 0,007 & 1,230 \\
\hline 3 & 0,0009 & 0,337 & 0,067 & 1,023 \\
\hline 4 & 0,0025 & 0,468 & 0,083 & 1,017 \\
\hline 5 & $-0,0023$ & $-0,810$ & 0,083 & 1,015 \\
\hline 6 & 0,0003 & 0,074 & 0,020 & 1,087 \\
\hline
\end{tabular}

Keterangan:

*signifikan pada tingkat $10 \%$ ( $t>1,711$ untuk pengujian dua sisi dengan $k=25)$

**signifikan pada tingkat 5\% ( $t>2,064$ untuk pengujian dua sisi dengan $k=25)$

***signifikan pada tingkat 1\% $(t>2,797$ untuk pengujian dua sisi dengan $k=25)$

Berdasarkan hasil signifikansi rata-rata $\mathrm{AR}$ dan rata-rata TVA periode 9 untuk masing-masing hari event window berarti penerbitan Indeks SRI-KEHATI tidak mengandung informasi, sehingga pasar tidak bereaksi pada periode 9 penerbitan indeks ini. Hasil uji $t$ periode 1 sampai dengan periode 9 diringkas pada Tabel 11.

Berdasarkan hasil uji $t$, reaksi pasar modal yang diukur dengan variabel rata-rata $\mathrm{AR}$ dan rata-rata TVA menghasilkan kesimpulan yang berbeda. Reaksi pasar modal pada periode 1 dan 2 penerbitan Indeks SRI-KEHATI menunjukkan tidak ada reaksi pasar baik diukur dengan rata-rata $A R$ maupun rata-rata TVA. Reaksi pasar mulai ada pada periode 3, tetapi setelah periode 3 hingga periode 9 tidak ada reaksi pasar apabila diukur dengan rata-rata AR. Berbeda dengan apabila diukur dengan rata-rata TVA, mulai periode 3 hingga periode 8 ada reaksi pasar. Periode 9 tidak ada reaksi pasar pada rata-rata $\mathrm{AR}$ dan rata-rata TVA.

\section{Pengujian Perbedaan AR dan TVA Sebelum dan Sesudah Penerbitan Indeks SRI-KEHATI}

Hasil pengujian hipotesis 2 disajikan mulai Tabel 12. Hasil uji Sign Test variabel AR menunjukkan nilai asymp sign (2-tailed) $>0,05$ pada 9 periode pengamatan yang berarti tidak ada perbedaan AR sebelum dan sesudah penerbitan Indeks SRIKEHATI, sedangkan pada periode 3, nilai asymp sign (2-tailed) sebesar 0,06 mendekati 0,05. Hasil ini mendekati sama dengan hasil uji $t$ yang menunjukkan bahwa tidak ada reaksi pasar pada periode 1 sampai dengan periode 9 , hanya pada periode 3 ada reaksi pasar. Hal ini menunjukkan tidak ada perbedaan variabel AR sebelum dan sesudah penerbitan Indeks SRI-KEHATI, yang berarti pasar modal tidak merespon penerbitan Indeks SRI-KEHATI selama 9 periode.

Hasil uji Sign Test variabel TVA menunjukkan nilai asymp sign (2-tailed) $>0,05$ pada periode 1, 2, 4, $5,7,8$, dan 9 yang berarti tidak ada perbedaan TVA yang signifikan sebelum dan sesudah penerbitan Indeks SRI-KEHATI. Periode 3 dan 6 nilai asymp sign (2-tailed) $<0,05$ yang berarti pada periode 3 dan 6 ada perbedaan TVA sebelum dan sesudah penerbitan Indeks SRI-KEHATI. Hal ini menunjukkan tidak konsistensinya perbedaan variabel TVA sebelum dan sesudah penerbitan Indeks SRI-KEHATI selama 9 periode.

\section{Pembahasan}

Pengujian reaksi pasar modal Indonesia terhadap pengumuman indeks SRI-KEHATI selama sembilan periode menunjukkan hasil bahwa tidak ada reaksi pasar pada dua periode awal pengumuman indeks baik diukur dengan rata-rata AR dan rata-rata TVA. Hal ini dapat disebabkan karena indeks ini belum dikenal oleh semua investor. Periode 3 ada reaksi pasar yang siginifikan baik diukur dengan rata-rata AR maupun rata-rata TVA. Hal ini menunjukkan bahwa investor mulai mengetahui keberadaan indeks ini. Ada perbedaan hasil antara pengukuran rata-rata $\mathrm{AR}$ dan rata-rata TVA pada periode 4 hingga periode 9. Secara konsisten pasar tidak beraksi 
Tabel 11

Reaksi Pasar Modal selama 9 Periode dengan Event Window -6 s/d +6

\begin{tabular}{cll}
\hline \multirow{2}{*}{ Periode } & \multicolumn{1}{c}{ Abnormal Return } & \multicolumn{1}{c}{ Reaksi Pasar } \\
\cline { 2 - 3 } & Tidak ada reaksi pada hari ke $-6 \mathrm{~s} / \mathrm{d}+6$ & Tidak ada reaksi pada hari ke $-6 \mathrm{~s} / \mathrm{d}+6$ \\
2 & Tidak ada reaksi pada hari ke $-6 \mathrm{~s} / \mathrm{d}+6$ & Tidak ada reaksi pada hari ke $-6 \mathrm{~s} / \mathrm{d}+6$ \\
3 & Ada reaksi pada hari ke $-4,-3,-2,0,1,2,4,5,6$ & Tidak Ada reaksi pada hari ke $-6 \mathrm{~s} / \mathrm{d}+6$ \\
& Tidak ada reaksi pada hari ke- $-6,-5,3$ & \\
& Tidak ada reaksi pada hari ke- $-6 \mathrm{~s} / \mathrm{d}+6$ & Ada reaksi reaksi pada hari ke $-6 \mathrm{~s} / \mathrm{d}+6$ \\
5 & Tidak ada reaksi pada hari ke $-6 \mathrm{~s} / \mathrm{d}+6$ & Ada reaksi pada hari ke $-6,-5,-3,-2 \mathrm{~d}, 1,2,4$ \\
6 & Tidak ada reaksi pada hari ke $-6 \mathrm{~s} / \mathrm{d}+6$ & Tidak ada reaksi pada hari ke $-4,-1,3,5,6$ \\
7 & Tidak ada reaksi pada hari ke $-6 \mathrm{~s} / \mathrm{d}+6$ & Ada reaksi pada hari ke $-6 \mathrm{~s} / \mathrm{d}+6$ \\
8 & Ada reaksi pada hari ke $-6,-5,-4$ & Ada reaksi pada hari ke $-6 \mathrm{~s} / \mathrm{d}+6$ \\
9 & Tidak ada reaksi pada hari ke $-3 \mathrm{~s} / \mathrm{d} 6$ & Ada reaksi pada hari ke $-6 \mathrm{~s} / \mathrm{d}+6$ \\
& Tidak ada reaksi pada hari ke $-6 \mathrm{~s} / \mathrm{d}+6$ & Tidak ada reaksi pada hari ke -1 \\
& & Tidak ada reaksi pada hari ke $-6 \mathrm{~s} / \mathrm{d}+6$ \\
\hline
\end{tabular}

Tabel 12

Uji Dua Sampel Berpasangan

\begin{tabular}{|c|c|c|c|c|c|c|c|c|c|c|}
\hline \multirow{2}{*}{ Var } & \multirow{2}{*}{ Sign Test } & \multicolumn{9}{|c|}{ Periode } \\
\hline & & 1 & 2 & 3 & 4 & 5 & 6 & 7 & 8 & 9 \\
\hline \multirow{2}{*}{$\mathrm{AR}$} & $Z$ & $-0,41$ & $-0,57$ & $-1,88$ & $-0,25$ & $-0,25$ & $-0,57$ & $-0,08$ & $-1,06$ & $-0,89$ \\
\hline & Asymp. Sig. (2-tailed) & 0,68 & 0,57 & 0,06 & 0,81 & 0,81 & 0,57 & 0,94 & 0,29 & 0,37 \\
\hline \multirow{2}{*}{ LNTVA } & $Z$ & $-1,39$ & 0,00 & $-4,49$ & $-1,41$ & 0,00 & $-2,69$ & $-1,80$ & $-0,82$ & $-1,49$ \\
\hline & Asymp. Sig. (2-tailed) & 0,17 & 1,00 & $0,00 *$ & 0,16 & 1,00 & $0,01 *$ & 0,07 & 0,41 & 0,14 \\
\hline
\end{tabular}

Keterangan:

* Asymp. Sig. (2-tailed) < 0,05 berarti Ho diterima.

terhadap keberadaan indeks SRI-KEHATI selama 4,5 tahun atau 9 periode pengumuman bila diukur dengan rata-rata $\mathrm{AR}$, namun tidak konsisten bila diukur dengan rata-rata TVA. Hasil penelitian ini sejalan dengan penelitian Tangketasik (2010), Renovan (2012), dan Kusumawardani (2012).

Temuan ini mencerminkan bahwa investor di pasar modal Indonesia belum sepenuhnya berorientasi lingkungan dan kemanusiaan. Investor masih mempertanyakan kinerja dari indeks ini mengingat indeks SRI-KEHATI belum sepopuler indeks-indeks terdahulu seperti indeks LQ45 dan Jakarta Islamic Index (JII).

Perilaku investor di pasar modal Indonesia ini sejalan dengan perilaku investor di São Paulo Stock Exchange (Nossa, et al. 2009; Anderson-Weir (2010) yang menunjukkan bahwa investor di Amerika Serikat adalah investor yang tidak peduli lingkungan. Hal ini tidak sejalan dengan penelitian penelitian Bettenhausen et al. (2010) yang menemukan bahwa investor di Amerika Serikat adalah investor yang peduli lingkungan.

\section{Simpulan dan Implikasi}

Hasil penelitian menunjukkan berdasarkan hasil uji $t$, reaksi pasar modal yang diukur dengan variabel rata-rata AR dan rata-rata TVA menghasilkan kesim- pulan yang berbeda. Hasil uji Sign Test variabel AR menunjukkan secara konsisten tidak ada perbedaan variabel AR sebelum dan sesudah penerbitan Indeks SRI-KEHATI selama sembilan periode, yang berarti pasar modal tidak merespon penerbitan Indeks SRI-KEHATI selama sembilan periode.

Hasil uji Sign Test variabel TVA menunjukkan pada periode 1, 2, 4, 5, 7, 8, dan 9 tidak ada perbedaan TVA sebelum dan sesudah penerbitan Indeks SRIKEHATI. Periode 3 dan 6 ada perbedaan TVA sebelum dan sesudah penerbitan Indeks SRI-KEHATI. Hal ini menunjukkan tidak konsistensinya perbedaan variabel TVA sebelum dan sesudah penerbitan Indeks SRI-KEHATI selama sembilan periode. Hal ini mencerminkan bahwa investor di pasar modal Indonesia belum sepenuhnya berorientasi lingkungan dan kemanusiaan atau investor masih mempertanyakan kinerja dari indeks ini.

Penelitian yang terus menerus terkait Indeks SRI-KEHATI diharapkan memiliki implikasi bagi penyempurnaan penilaian suatu perusahaan oleh Yayasan KEHATI. Indeks ini diharapkan dapat menjadi acuan dalam pemilihan saham bagi investor dan sebagai motivasi bagi emiten untuk memperbaiki kinerjanya di bidang lingkungan agar terwujud perusahaan Indonesia yang peduli kepada lingkungan dan kemanusiaan. 
Penelitian berikutnya dapat dilakukan dengan mengukur kinerja Indeks SRI-KEHATI mengingat indeks ini masih relatif baru sehingga tingkat kepercayaan investor terhadap indeks ini masih relatif rendah.

\section{Daftar Referensi}

Anderson-Weir, C. H. (2010). How does the stock market react to corporate environmental news? Undergraduate Economic Review, 6(1), article 9.

Bettenhausen, K., Byrd, J., \& Cooperman, E. S. (2010). Environmental risk and shareholderreturns: Evidence from the announcement of the Toxic 100 Index. International Review of Accounting, Banking and Finance, 2(3), 28-45.

Bursa Efek Indonesia. (2010). Buku panduan indeks harga saham bursa efek Indonesia. Retrieved March 13, 2013 from http://www.idx.co.id/Portals/0/Information/ForInvestor/StockMarketIndicies.
Jogiyanto, H. M. (2003). Teori portofolio dan analisis investasi. Edisi 3. Yogyakarta: BPF.

Kusumawardani, N. F. (2012). Reaksi pasar terhadap penerbitan penerbitan indeks SRI-KEHATI. Skripsi. Malang: STIE Malangkucecwara.

Nossa, V., Cezar, J. F., Silva Júnior, A., Baptista, E. C. S., \& Nossa, S. N. (2009). The relationship between abnormal returns and social and environmental responsibility: An empirical study of companies traded on the bovespa from 1999 to 2006. Brazilian Business Review, 6(2), 121136.

Renovan, R. (2012). Pengaruh peluncuran indeks srikehati terhadap pasar modal Indonesia. Skripsi. Malang: Universitas Ma Chung.

Tangketasik, A. (2010). Pengujian efisiensi pasar bentuk setengah kuat secara informasi: Peluncuran indeks sri-kehati (suatu studi empiris pada perusahaan yang termasuk dalam indeks srikehati yang tercatat di Bursa Efek Indonesia). Skripsi. Surabaya: STIE Perbanas. 